\title{
Projections of climate change impacts on central America tropical rainforest
}

\author{
André Lyra $^{1}$ (D) Pablo Imbach ${ }^{2} \cdot$ Daniel Rodriguez $^{1}$ • \\ Sin Chan Chou ${ }^{1} \cdot$ Selena Georgiou $^{2} \cdot$ Lucas Garofolo $^{1}$
}

Received: 7 October 2015 / Accepted: 26 August 2016 / Published online: 7 September 2016

(C) Springer Science+Business Media Dordrecht 2016

\begin{abstract}
Tropical rainforest plays an important role in the global carbon cycle, accounting for a large part of global net primary productivity and contributing to $\mathrm{CO}_{2}$ sequestration. The objective of this work is to simulate potential changes in the rainforest biome in Central America subject to anthropogenic climate change under two emissions scenarios, RCP4.5 and RCP8.5. The use of a dynamic vegetation model and climate change scenarios is an approach to investigate, assess or anticipate how biomes respond to climate change. In this work, the Inland dynamic vegetation model was driven by the Eta regional climate model simulations. These simulations accept boundary conditions from HadGEM2-ES runs in the two emissions scenarios. The possible consequences of regional climate change on vegetation properties, such as biomass, net primary production and changes in forest extent and distribution, were investigated. The Inland model projections show reductions in tropical forest cover in both scenarios. The reduction of tropical forest cover is greater in RCP8.5. The Inland model projects biomass increases where tropical forest remains due to the $\mathrm{CO}_{2}$ fertilization effect. The future distribution of predominant vegetation shows that some areas of tropical rainforest in Central America are replaced by savannah and grassland in RCP4.5. Inland projections under both RCP4.5 and RCP8.5 show a net primary productivity reduction trend due to significant tropical forest reduction, temperature increase, precipitation reduction and dry spell increments, despite the biomass increases in some areas of Costa Rica and Panama. This study may provide guidance to adaptation studies of climate change impacts on the tropical rainforests in Central America.
\end{abstract}

This article is part of a Special Issue on "Climate change impacts on ecosystems, agriculture and smallholder farmers in Central America” edited by Camila I. Donatti and Lee Hannah.

André Lyra

andre.lyra@cptec.inpe.br

1 National Institute for Space Research - INPE, Rod Pres Dutra km 39, Cachoeira Paulista, SP CEP: 12630-000, Brazil

2 Tropical Agricultural Research and Higher Education Center - CATIE 7170, Turrialba, Cartago 30501, Costa Rica 


\section{Introduction}

The effects of climate change may have direct impacts on vegetation such as changes in productivity, functional trait composition, species extinction or range redistribution. These changes may be associated with increased drought stress (Malhi et al. 2009), drying or dieback (Cox et al. 2000). Climate change can also have indirect impacts on vegetation such as increased fire frequency (Scholze et al. 2006). Global and regional climate simulations for the next few decades project changes in precipitation and warming that may severely impact major biomes all over the world (IPCC 2013). Central America is a biodiversity hotspot area, and the region's governments have demonstrated their commitment to biodiversity conservation through the Mesoamerican Biological Corridor (Holland 2012). However, future climate change can alter the composition and distribution of species (Parry et al. 2007) and ecosystems (Imbach et al. 2013), leading to a need for conservation strategies to be reassessed. Projections of the possible impacts of climate change on ecosystems can help support assessments of conservation needs and adaptation measures in the region.

Tropical rainforest plays an important role in the global carbon cycle (Malhi and Grace 2000; Huntingford et al. 2013), accounting for a large part of global net primary productivity (NPP) and lowering atmospheric $\mathrm{CO}_{2}$ levels. The Central American rainforests are mainly found on the Caribbean watersheds of Panama, Costa Rica, Honduras, Belize, and southern Mexico. The region is a global biodiversity hotspot (Meyers et al. 2000; Mauri 2002) that are highly threatened by land use change. In Central America, impacts similar to those that occurred during El Niño years are expected to increase under future climate scenarios (Karmalkar et al. 2011). Similar to the Amazon, Central America is subject to potentially large losses of forest biomass under increased drying and warming scenarios in the twenty-first century (Lyra et al. 2016; Imbach et al. 2012; Cox et al. 2000; Cox et al. 2004; Betts et al. 2004).

Imbach et al. (2012) used 136 GCM (General Circulation Model) realizations within a biogeographic model, MAPSS (Mapped Atmosphere Plant Soil System), to evaluate the likelihood and magnitude of impacts of climate change on vegetation under three climate change emissions scenarios (A2, A1B and B1). The coarse resolutions of the GCM data, as well as the use of MAPSS, suggest some limitations of the work. MAPSS is an equilibrium model with limited capability to categorize plant functional types and dynamically represent growth constraints. Therefore, the use of a new approach to refine these early estimates can be useful in understanding impacts and uncertainties.

The use of a dynamic vegetation model within a regional climate model is a powerful approach to assess potential responses of biomes to climate change. Dynamic vegetation models may include plant phenology, plant physiology, biogeochemical cycles, mortality and growth processes. The model can simulate competition and shifts in vegetation during long periods of strong climatic changes such as temperature or precipitation changes. Dynamic vegetation models should simulate the suppression and replacement of vegetation types or vegetation regeneration processes. Dynamic vegetation models can simulate transient changes in global vegetation patterns under future climate change and human disturbance scenarios (Peng 2000). Dynamic vegetation models can also be used to estimate the transient behaviors of terrestrial carbon pools and fluxes (including possible effects of $\mathrm{CO}_{2}$ fertilization), climate variability, and ecosystem disturbances (Peng 2000). When coupled to a GCM, dynamic vegetation models can provide a fully interactive representation of biosphere ecosystems to investigate the biosphereatmosphere feedbacks. 
The narrow shape of Central America requires the use of higher horizontal resolution assessments to capture the effects of topography on local climate. Therefore, coupling a dynamic vegetation model to a high-resolution regional climate model is appropriate for this area. The objective of this work is to investigate the possible changes in the rainforest biome in Central America subject to two climate change scenarios, RCP4.5 and RCP8.5 (representative concentration pathways). Possible changes are investigated using the Inland dynamic vegetation model and Eta regional model to assess long-term feedbacks between Central American biomes and climate, including the potential effects of increased atmospheric $\mathrm{CO}_{2}$ concentrations. This is the first time a high-resolution regional climate model has been used to force a dynamic vegetation model to study the impacts of climate change on Central American rainforests.

\section{Methodology}

A dynamic vegetation model and climate change scenarios were used to investigate vegetation response to changes in climate. A brief description of the Inland dynamic vegetation model is provided, followed by the descriptions of the Eta regional climate model and the HadGEM2ES global climate model.

\subsection{Inland dynamic vegetation model}

The Inland (Integrated Model of Land Surface Processes) model was developed using IBIS (Integrated Biosphere Simulator, Foley et al. 1996) to represent the processes of the Earth's surface. The primary focus of the Inland model is to represent Brazilian ecosystems and biomes of tropical South America. Compared to IBIS, the Inland model has improved representations of biosphere-atmosphere interactions, such as with croplands. The Inland model specifically integrates major Brazilian crops, floodplain dynamics, and the transient land cover dynamics that characterize the Amazon and Cerrado regions. Although Inland is being developed in Brazil, it is a global dynamic vegetation model that contains major global biome types and representations of the relevant processes in the tropics. Evaluation of surface fluxes and more thorough descriptions of the Inland model's operation over Amazonia can be found in Lyra (2015) and Lyra et al. (2016).

The Inland model is divided into four modules: land surface, vegetation phenology, carbon balance and dynamic vegetation, which operate on a common grid at different time steps. Vegetation composition is described by 12 different plant functional types (PFTs), which are distinguished according to their bioclimatic (boreal, temperate or tropical), physiological (C3 or $\mathrm{C} 4$ photosynthesis), leaf form (broadleaf, needleleaf or herbaceous), morphological (tree or grass) and phenological (deciduous or evergreen) attributes. The model runs on a regular latitude-longitude grid of $0.5^{\circ}$ resolution. The inputs are daily measures of temperature, precipitation, cloud cover, specific humidity and wind speed. Photosynthesis is calculated with the Farquhar-Collatz method (Farquhar et al. 1980; Collatz et al. 1992). The model allows for the coexistence of one or more PFTs per grid cell. The initial type of vegetation cover in the Central American and Caribbean region is shown in Fig. 1. The existence of a PFT within a grid cell depends on its specific environmental limits and competition for light, water and nutrients with other co-existing PFTs. Vegetation dynamics are simulated annually based 
on the leaf area index (LAI) and NPP of the different PFTs while accounting for climate, disturbance, mortality and establishment factors. Neither fire nor nutrient feedback processes are included in the simulation.

\subsection{Downscaling climate scenarios}

The regional Eta model is used for downscaling climate scenarios. The Eta is a numerical atmospheric model used to produce weather and climate forecasts for South America by the Brazilian National Institute for Space Research (INPE). The version for climate change studies was developed (Pesquero et al. 2009; Chou et al. 2012) to support the Brazilian National Communications to the United Nations Framework Convention on Climate Change. Eta is a regional climate model that uses the Eta vertical coordinate system (Mesinger 1984). Precipitation is simulated in the model by the Betts-Miller-Janjic cumulus parameterization scheme (Janjić 1984) and by the Zhao cloud microphysics scheme (Zhao et al. 1997). The land-surface transfer processes are parameterized by the NOAH scheme (Ek et al. 2003). The radiation package was developed by the Geophysical Fluid Dynamics Laboratory and includes short-wave (Lacis and Hansen 1974) and long-wave radiation (Fels and Schwarzkopf 1975). The radiation tendencies are recalculated every hour and are applied at every time step. $\mathrm{CO}_{2}$ equivalent concentrations for the RCP4.5 and RCP8.5 scenarios have been updated every three years since 2005. The atmospheric turbulence scheme has the turbulent kinetic energy as a prognostic variable. Monin-Obukhov similarity theory is combined with Paulson stability functions (Paulson 1970) and applied at the surface layer to describe the logarithmic wind profile. The Earth System configuration of the UK Met Office Hadley Centre Global Environmental Model, version 2 (HadGEM2-ES) supplies the lateral boundary conditions used to drive the Eta regional climate model (Collins et al. 2008). The global model variables that force the regional model are air temperature, humidity, winds, surface pressure and sea surface temperature.

A more detailed description of the Eta model and recent improvements, such as the refined vertical coordinate system and the implementation of the fully finite-volume dynamics, can be found in Mesinger et al. (2012). Details about the HadGEM2-ES CMIP5 model and on how this model is run can be found in Jones et al. (2011). Evaluations of the regionalized baseline simulation and the assessment of projections used in this work are available in Chou et al.

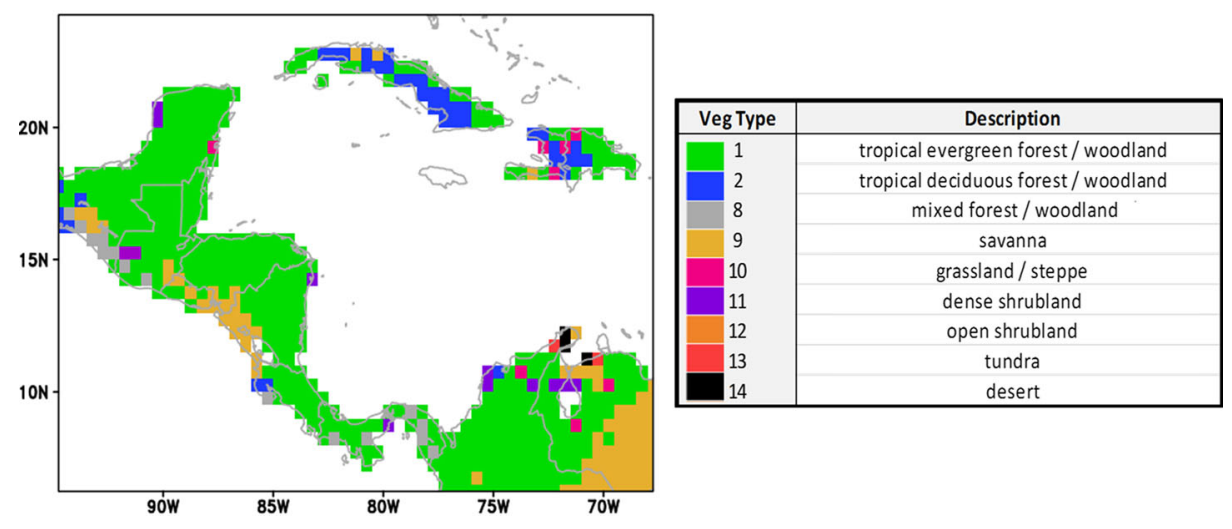

Fig. 1 Initial vegetation type in Central America and Caribbean 
(2014 a, b) , respectively. Because the baseline simulation and observed data are in agreement, these climate scenarios can be used to force impact models.

\subsection{Experimental setup}

Using the same methodology as Lyra et al. (2016), the Inland model was forced by the regional Eta model runs in the two RCP scenarios. Under the RCP4.5 scenario, the radiative forcing increases almost linearly up to about 2060, when the rate slows, until eventual stabilization at the end of the century. The RCP8.5 scenario is characterized by a continuous increase in greenhouse gas emissions, beyond 2100. The Inland model domain covers Central America, south of Mexico, and north of Colombia and Venezuela as shown in Fig. 1. The integration encompassed the period between 1961 and 2098 during which the $\mathrm{CO}_{2}$ equivalent concentration was updated according to each RCP scenario. The initial vegetation of the Inland model (Fig. 1) represents the potential vegetation reached from an equilibrium condition (Haxeltine and Prentice 1996; Foley et al. 1998). The Inland model simulations used daily values of 2-m temperature (mean, maximum and minimum), cloud cover, precipitation, specific humidity and wind speed from Eta-HadGEM2-ES runs.

The Eta Model nested in the HadGEM2-ES was configured with 20-km horizontal resolution, and 38 layers in the vertical and lateral boundary conditions were updated every six hours. The Eta model domain covers South America, Central America and the Caribbean. Despite the high resolution of the regional Eta model, Inland was set up at 0.5-degree regular latitude-longitude resolution, which was the same resolution as the input land-surface maps such as those for vegetation and soil.

\subsection{Forest cover and dry spell calculations}

The changes in forest extent predicted by the Inland model were assessed by comparing the percentage of tree cover in the last ten years of the twenty-first century to the percentage of tree cover in the ten years between 1961 and 1970 (Fig. 5). The ten-year period was chosen to highlight the major changes at the end of the century. The fractional cover of trees was estimated based on PFT leaf area index (LAI) following the Kucharik et al. (2000) equation for tropical broadleaf evergreen PFT (Eq. 1).

$$
\mathrm{F}_{\mathrm{PFTcover}}=1-\exp \left(-0.5 * \mathrm{LAI}_{\text {tree }}\right)
$$

The empirical canopy extinction coefficient is 0.5 , and $\mathrm{LAI}_{\text {tree }}$ is the total leaf area index of all tree PFTs in a pixel.

Dry spell occurrences were identified following the water balance approach developed by Barron et al. (2003), which focuses on dry spells in relation to water consumption by vegetation. Dry spells are particularly important in delimiting tropical vegetation types. In the Barron approach, a dry spell is defined as two or more consecutive days when the relationship between actual evapotranspiration (ETa) and potential evapotranspiration (ETp) is lower than or equal to 0.5. Potential evapotranspiration is calculated with the Penman-Monteith approach, using both baseline and projections of meteorological data. Actual evapotranspiration is obtained from the atmospheric model estimations. 


\section{Results}

The possible influence of regional climate change on vegetation properties, such as biomass, NPP, and changes in forest extent and distribution, were investigated. We first present temperature and precipitation changes to provide context necessary for understanding vegetation changes. An analysis of dry spells is performed for additional depth of insight into vegetation changes due to water stress. Then vegetation type and biomass changes are explored.

\subsection{Climate projections}

Climate projections provided by Eta-HadGEM2-ES show warming of about 3 to $3.5^{\circ} \mathrm{C}$ in the inner areas of the region in RCP4.5 (Fig. 2a) and of about 6 and $7{ }^{\circ} \mathrm{C}$ in RCP8.5 by the end of the century (Fig. 2b). Reductions in precipitation dominate future simulations, especially in lowland areas of the Pacific and Caribbean watersheds in all countries (Guatemala, El Salvador, Belize, Honduras, Nicaragua, Costa Rica and Panamá). This drier future trend is partially inherited from the driver HadGEM2-ES model, which shows precipitation reductions in the future.

Precipitation decreases 3-4 and $6 \mathrm{~mm}$ /day depending on the global warming scenario, RCP4.5 and RCP8.5, respectively (Fig. 3). Karmalkar et al. (2011) assessed the climate change in this region under A2 SRES (Nakicenovic et al. 2000) scenarios and also noted the generalized reduction of precipitation seen in our simulations. However, other studies based on mean future climatology indicate higher uncertainties for precipitation anomalies over Costa Rica and Panama (Imbach et al. 2012). According to Stevens and Bony (2013), there are many differences among the simulations of global models for the tropics due to uncertainties associated with the response of clouds and precipitation and the representation of the processes in each model. This drying effect from the HadGEM2 model is probably not universal in all global climate models.

Dry spell durations were projected to increase by the end of the century in both scenarios. This increase over Mesoamerica is contrasted with a projected decrease in dry spell duration over South America. However, regional variations are evident in both scenarios, especially over the southern part of Mesoamerica, where decreasing dry spell duration is projected along both Pacific and Atlantic coastlines. Over the northern part of South America, increase in the

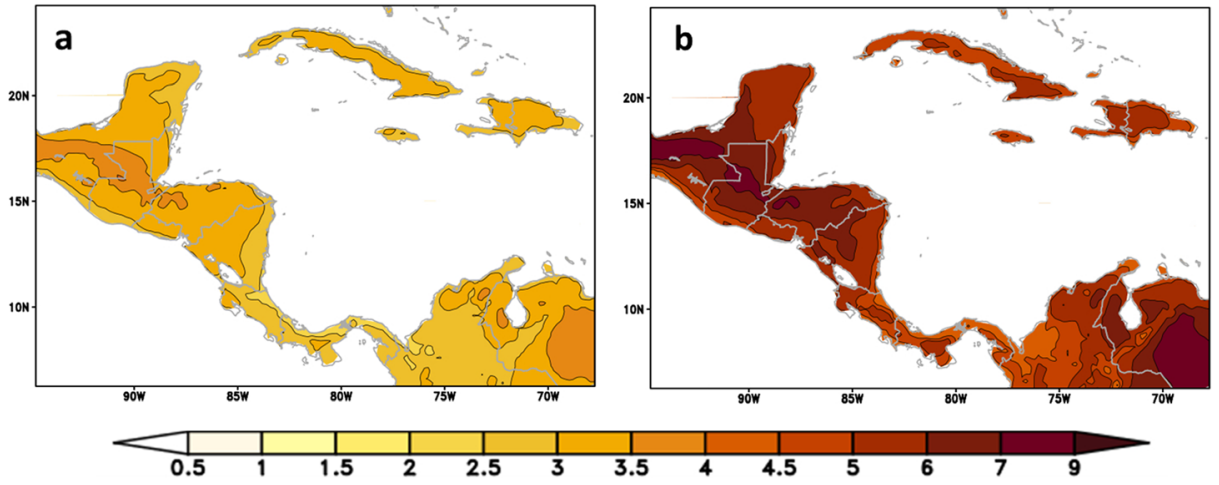

Fig. 2 Difference between the baseline (1961-1990) and the future (2071-2100) annual mean temperature $\left({ }^{\circ} \mathrm{C}\right)$ simulated by the Eta-HadGEM2 model for the a RCP4.5 and b RCP8.5 scenarios 


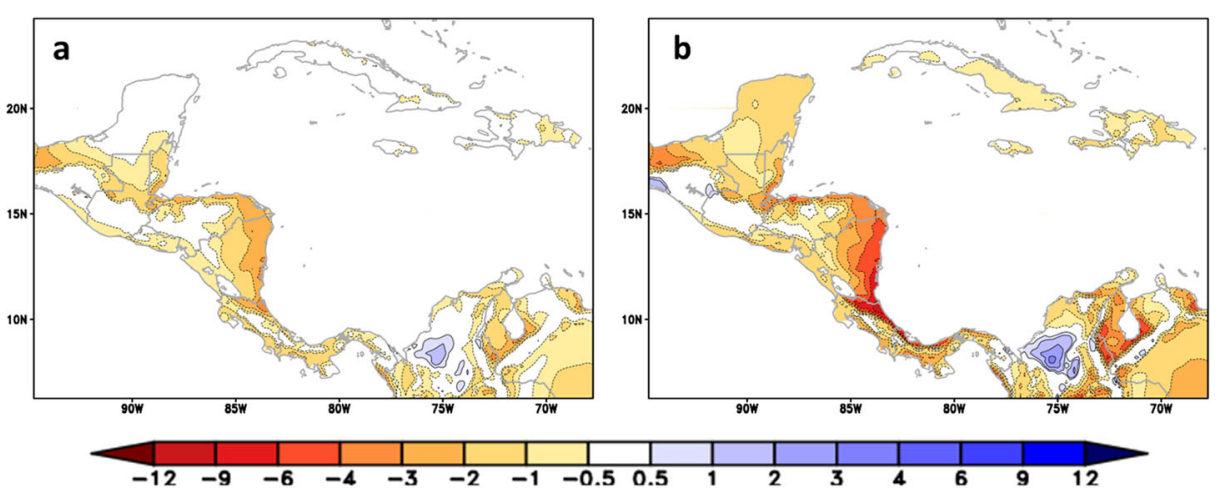

Fig. 3 Difference between the baseline (1961-1990) and the future (2070-2100) annual mean precipitation (mm/day) simulated by the Eta-HadGEM2 model for the a RCP4.5 and b RCP8.5 scenarios

length of dry spell duration are located in mountain chains, meanwhile in hillslopes and valleys there is a decrease in the length of dry spells. Projections under RCP 8.5 show the driest conditions, with the maximum number of consecutive dry days increasing to more than 100 days in the Yucatan Peninsula, the Pacific coastline in Honduras, the Cordillera Central in Panamá, the Andes in Colombia, the Caribbean coastline in Venezuela and Colombia and the Caribbean Islands. Longer dry spells could greatly impact vegetation growth by the end of the century by limiting water availability.

\subsection{Vegetation changes}

The Inland model RCP4.5 and RCP8.5 projections show reduction in tropical forest cover, with higher reduction under the RCP8.5 scenario (Fig. 5). Countries such as Costa Rica and Panama, which have relatively large annual precipitation, show little changes in tree vegetation cover. However, countries such as Nicaragua, Honduras, Guatemala and the southern part of Mexico exhibit large forest cover reductions over the Caribbean watershed. These results agree with the increasing duration of dry spells in the region (Figs. 4 and 5).
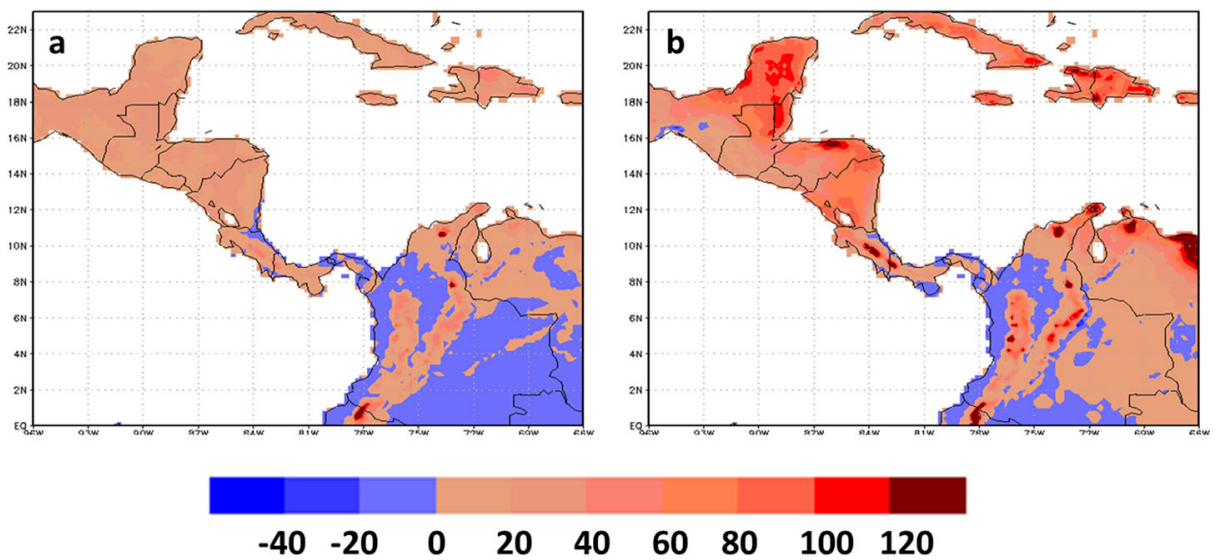

Fig. 4 Difference between the baseline (1961-1990) and the future (2070-2100) dry spells (days) projected by the Eta-HadGEM2 simulations for the a RCP4.5 and b RCP8.5 scenarios 
Figure 6 shows the spatial distribution of biomass for the initial period (1961-1970) and the differences in biomass distribution at the end of century for RCP4.5 and RCP8.5 scenarios. In the first ten years of simulations, the highest values of biomass (Fig. 6a) coincide with grid points covered by tropical evergreen forests (Fig. 1). The simulated biomass for the 19611970 period was compared to biomass maps from Saatchi et al. (2011). In general, the Inland model underestimates the biomass in forest areas in Nicaragua, Honduras, and Guatemala. The projected increase in biomass by the Inland model in areas covered by remaining tropical forest in Costa Rica and Panama can be attributed to the feedback effect of $\mathrm{CO}_{2}$ fertilization. This forest is absorbing more carbon under drier conditions due to increased water use efficiency (WUE), as stomata need to remain open for shorter periods because of enhanced atmospheric $\mathrm{CO}_{2}$.

In the northern part of the region, increased WUE cannot compensate for reduced water availability, therefore showing a reduction in biomass. The biomass decrease is about 4 to $6 \mathrm{~kg} /$ $\mathrm{m}^{2}$. In these areas and in both Inland simulations, the effects of rising temperatures (Fig. 2) and decreased precipitation (Fig. 3), projected by Eta-HadGEM2-ES simulations on vegetation, dominate over the effect of $\mathrm{CO}_{2}$ fertilization, leading to decreased productivity by the end of the century. These areas may also contribute to carbon loss to the atmosphere due to tree mortality and decomposition.

The total NPP is the difference between how much carbon dioxide the vegetation takes in during photosynthesis and how much carbon dioxide the vegetation releases during respiration. Various PFTs can co-exist in every pixel. Figure 7a shows the total NPP, 2-m temperature and precipitation projections for both RCPs averaged over an area $\left(-90^{\circ} \mathrm{W}\right.$ to $-80^{\circ} \mathrm{W}$ longitude and $10^{\circ} \mathrm{N}$ to $20^{\circ} \mathrm{N}$ latitude) covering Panama, Costa Rica, El Salvador, Honduras, Guatemala and Belize. Both simulations show a trend of NPP reduction due to tropical forest cover reduction, temperature increase, reductions in precipitation and increase in dry spells. Physiologically, the $\mathrm{CO}_{2}$ fertilization effect could increase the forest productivity. However, this process is offset by lower soil moisture availability driven by higher temperatures and decreases in precipitation. Figure $7 \mathrm{~b}$ shows the total biomass and soil moisture projections for both RCPs averaged over an area $\left(-90^{\circ} \mathrm{W}\right.$ to $-80^{\circ} \mathrm{W}$ longitude and $10^{\circ} \mathrm{N}$ to $20^{\circ} \mathrm{N}$ latitude). The total biomass shows a clear decrease after the $2050 \mathrm{~s}$, especially in the RCP8.5 scenario. This is in agreement with precipitation and soil moisture reductions in RCP8.5 (Figs. 7a, b, respectively).

The distribution of the predominant vegetation types simulated in the Inland model and projections of the Eta-HadGEM2-ES for both scenarios at the end of the century (between 2085 and 2095) are shown in Fig. 8. Some areas of tropical rainforest (tropical evergreen forest type) in Central America are replaced by savannah and grassland under the RCP4.5 scenario. Under RCP8.5, changes in vegetation cover are slightly larger. Projections also show that the areas over Costa Rica and Panama are less vulnerable to the climate change projected by the Eta-HadGEM2-ES model, although it still shows a reduction in tree cover (Fig. 5).

\section{Discussion}

The projected tropical rainforest area is reduced as simulations approach the end of century, and these projections differ between RCP4.5 and RCP8.5. These results are similar to those of Imbach et al. (2012), which were generated using an equilibrium modeling approach. Imbach et al. (2012) observed drier Pacific watershed ecosystems expanded over the more humid 


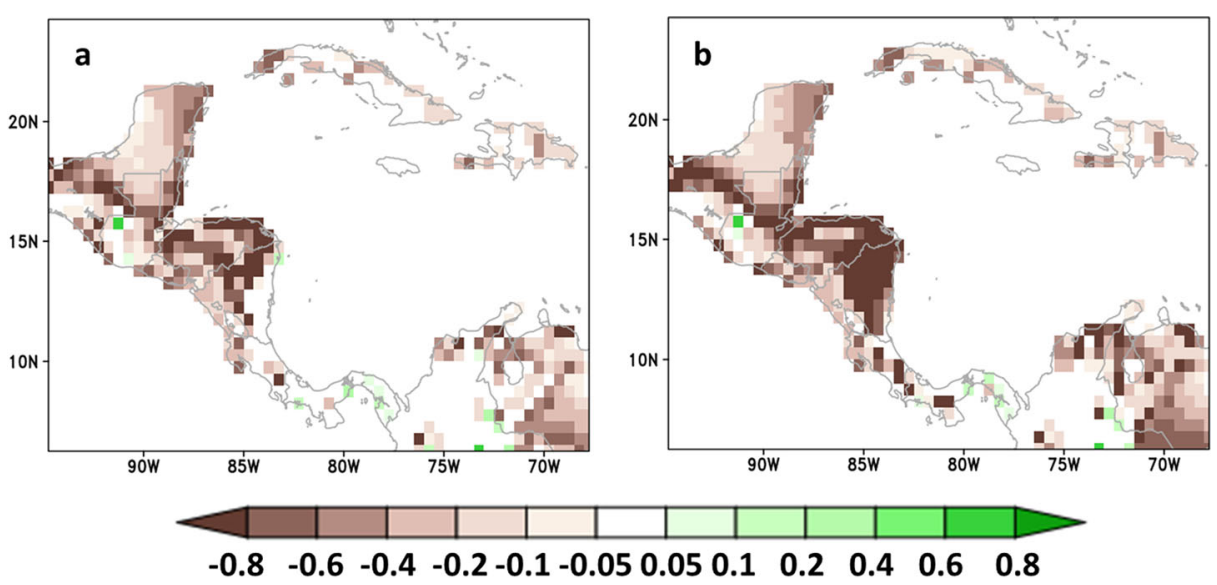

Fig. 5 Fractional changes in tree vegetation cover at the end of twenty-first century for the a RCP4.5 and $\mathbf{b}$ RCP8.5 scenarios

(currently) areas of the Caribbean under future climate scenarios. Imbach et al. (2012) also found significant effects of increased WUE on vegetation responses due to $\mathrm{CO}_{2}$ fertilization
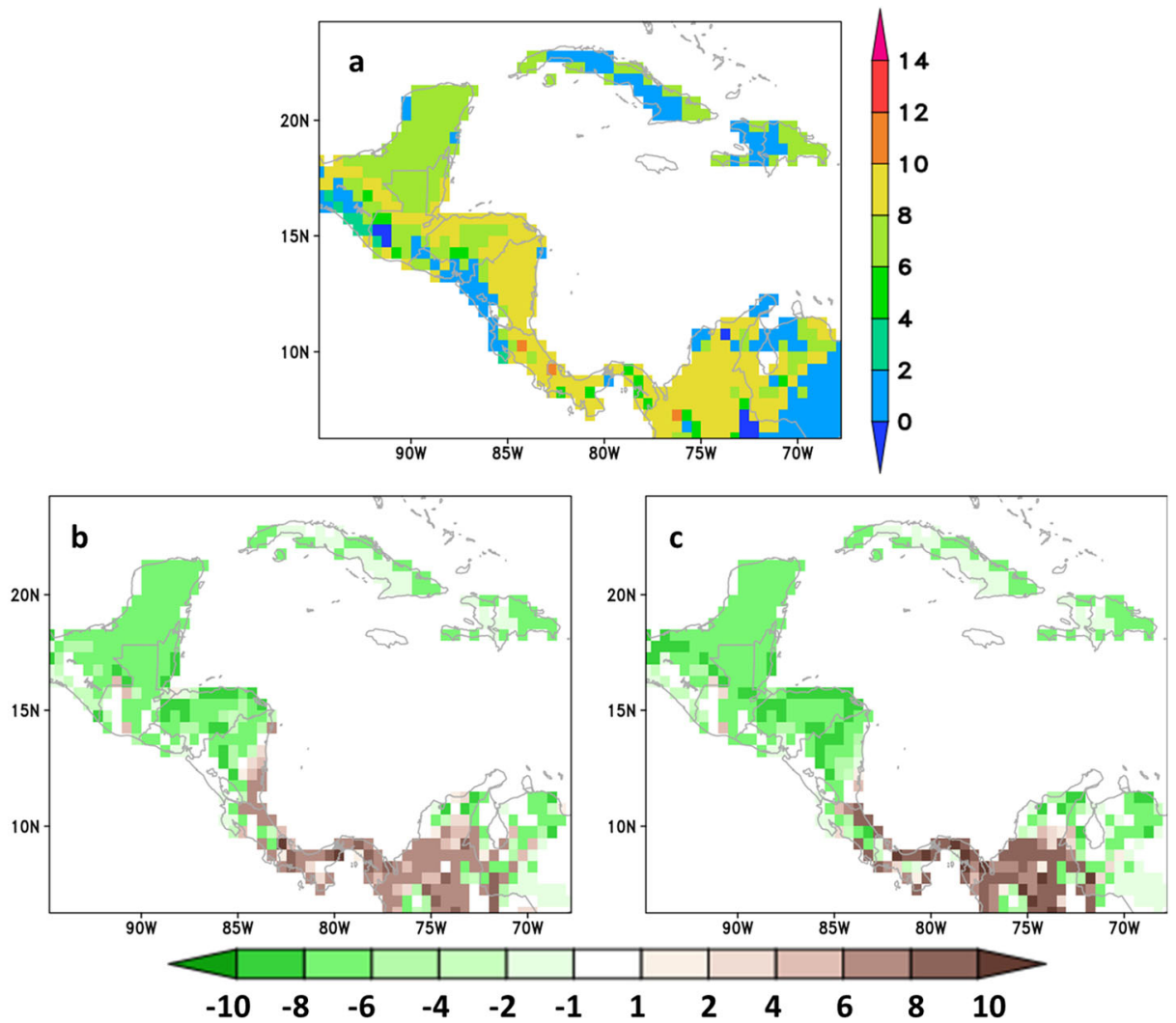

Fig. 6 Initial biomass $\left(\mathrm{kg} . \mathrm{m}^{-2}\right)$ for PFT tropical broadleaf evergreen $\mathbf{a}$, and difference of biomass at the end of twenty-first century for $\mathbf{b}$ RCP4.5 and $\mathbf{c}$ RCP 8.5 scenarios 

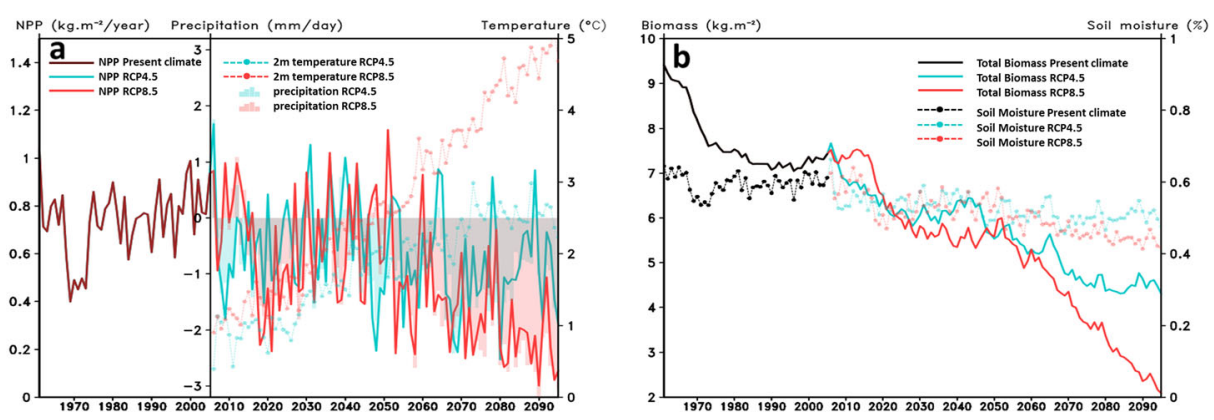

Fig. 7 a Total NPP (kg.m ${ }^{-2} /$ year), precipitation $\left(\mathrm{mm} /\right.$ day), and 2-m temperature $\left({ }^{\circ} \mathrm{C}\right)$ projected for $\mathrm{RCP} 4.5$ (blue) and RCP8.5 (red) and total NPP for present climate (brown). b Total biomass (kg.m ${ }^{-2}$ ) and soil moisture (\%) simulated for present climate (black lines) and projected for RCP4.5 (blue) and RCP8.5 (red)

and areas with potentially total tree cover loss. Areas initially covered with savannah and tropical deciduous forest vegetation are practically extinguished at the end of the century.

However, the Inland model simulations suggest that $\mathrm{CO}_{2}$ fertilization will enhance vegetation productivity in some forest areas even under climate scenarios where the overall extent of tropical forest is reduced. Inland model projections suggest that future climate change would have adverse effects on tropical rainforest region-wide. NPP decreases over Central America and so does biomass, particularly in the northern and eastern part of domain. The large annual variation in NPP can be attributed to frequent drought derived from the climate scenarios,

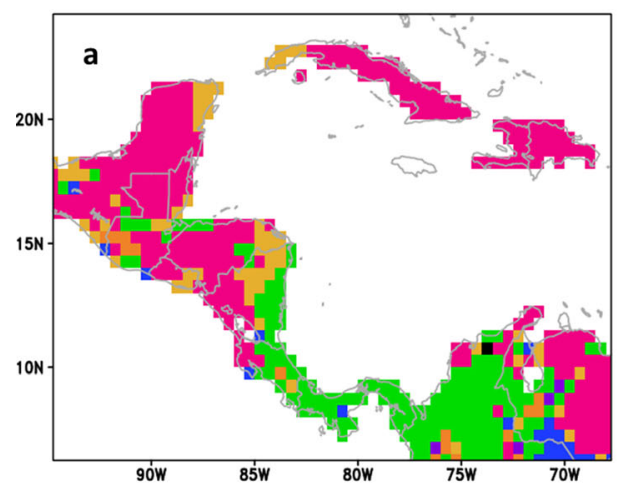

\begin{tabular}{|c|c|}
\hline Veg Type & Description \\
\hline 1 & tropical evergreen forest / woodland \\
2 & tropical deciduous forest / woodland \\
8 & mixed forest / woodland \\
9 & savanna \\
10 & grassland / steppe \\
11 & dense shrubland \\
12 & open shrubland \\
13 & tundra \\
\hline 14 & desert \\
\hline
\end{tabular}

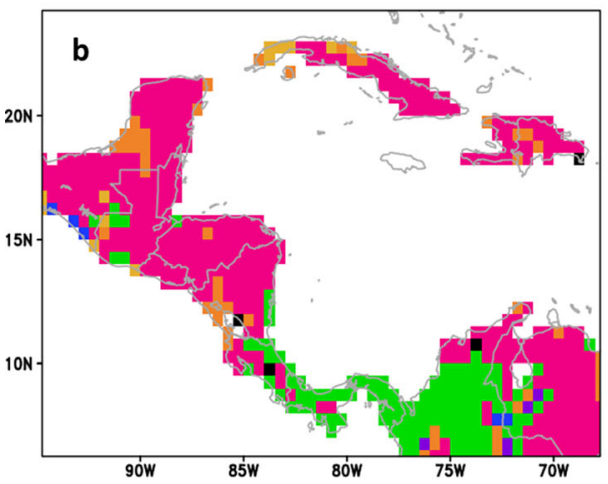

Fig. 8 End of twenty-first century vegetation cover for a RCP4.5 and b RCP8.5 scenario 
particularly in RCP8.5. The NPP projected under the RCP4.5 scenario exhibits a different trend from RCP8.5. This different trend could have been caused by more intense warming under RCP8.5 that suppresses the $\mathrm{CO}_{2}$ fertilization effect.

The projected changes in the distribution of the natural vegetation by the end of the twentyfirst century may have impacts on local circulation and water resources in the region. According to Jones et al. (2009), the global terrestrial biosphere can continue to change for decades after climate stabilization.

\section{Conclusions}

A dynamic vegetation model was driven by downscaling climate change scenarios to assess potential impacts on the tropical rainforests in Central America. The drier future scenarios indicated conversion of tropical rainforest to savannah and grassland. This result has implications for the $\mathrm{CO}_{2}$ feedback to the atmosphere. Changes in temperature and precipitation may exceed the natural adaptive response capacity of rainforest, causing forest dieback, which has serious implications for the global carbon cycle. Further, Central America is highly dependent on water resources, and the loss of forest may cause regional and local impacts on water availability and quality.

Our study provides insights for stakeholders and researchers studying impacts of climate change on the tropical rainforests of Central America. The framework used here can inform the potential magnitude of the impacts of climate change on the rainforest biome. Considering the outcome of United Nations Framework Convention on Climate Change Conference of Parties (COP21) in Paris in 2015 and the premise that the emissions should be close to the RCP4.5, which already shows considerable forest devastation for Central America in our simulations, the results obtained here support policies that run closer to the 1.5 degree warming target. The major forest reduction in Central America projected in this study may require more attention and suggests that additional areas may need to be prioritized for conservation to reduce impacts on biodiversity and water provisioning. The impacts shown here have implications for conservation practices and climate change adaptation strategies that should be developed and implemented to enhance the resilience of Central American forests to climate change.

Acknowledgments Thanks to BADC (Martin Juckes) for the GCM boundary conditions. This work was partially funded by Brazilian Ministry of Science Technology and Innovation (through UNDP BRA/10/G32), CGPDI, CAPES-ANA 88887.115869/2015-01 and CNPq 308035/2013-5. This work also received financial support from AC3 project from the International Development Research Centre (IDRC) Canada; and the CASCADE project, which is part of the International Climate Initiative (ICI). The German Federal Ministry for the Environment, Nature Conservation and Nuclear Safety (BMU) supports CASCADE on the basis of a decision adopted by the German Bundestag.

\section{References}

Betts RA, Cox PM, Collins M, Harris PP, Huntingford C, Jones CD (2004) The role of ecosystem-atmosphere interactions in simulated Amazonian precipitation decrease and forest dieback under global climate warming. Theor Appl Climatol 78:157-175 
Chou SC, Marengo JA, Lyra A, Sueiro G, Pesquero J, Alves LM, Kay G, Betts R, Chagas D, Gomes JL, Bustamante J, Tavares P (2012) Downscaling of South America present climate driven by 4-member HadCM3 runs. Clim Dyn 38:635-653

Chou SC, Lyra AA, Mourão C, Dereczynski C, Pilotto I, Gomes J, et al. (2014a) Evaluation of the eta simulations nested in three global climate models. American Journal of Climate Change 3:438-454. doi: 10.4236/ajcc.2014.35039

Chou SC, Lyra AA, Mourão C, Dereczynski C, Pilotto I, Gomes J, et al. (2014b) Assessment of climate change over South America under RCP 4.5 and 8.5 downscaling scenarios. American Journal of Climate Change 3: 512-527

Collatz GJ, Ribas-Carbo M, Berry JA (1992) Coupled photosynthesis-stomatal conductance model for leaves of C4 plants. Austr. J. Plant Physiol 19:519-538

Collins WJ, Bellouin N, Doutriaux-Boucher M, Gedney N, Hinton T, Jones CD et al (2008) Evaluation of the HadGEM2 model. Met Office Hadley Centre Technical Note no. HCTN 74, available from Met Office, FitzRoy Road, Exeter EX1 3 PB

Cox PM, Betts RA, Jones CD, Spall SA, Totterdell IJ (2000) Acceleration of global warming due to carbon-cycle feedbacks in a coupled climate model. Nature 408:184-187

Cox PM, Betts RA, Collins M, Harris PP, Huntingford C, Jones CD (2004) Amazonian forest dieback under climate-carbon cycle projectsions for the twenty-first century. Theor Appl Climatol 78:137156

Ek M, Mitchell KE, Lin Y, Rogers E, Grunmann P, Koren V, Gayno G, Tarpley JD (2003) Implementation of Noah land surface model advances in the National Centers for environmental prediction operational mesoscale eta model. J Geophys Res 108(D22):8851

Farquhar GD, von Caemmerer S, Berry JA (1980) A biochemical model of photosynthetic CO2 assimilation in leaves of C3 species. Planta 149:78-90

Fels SB, Schwarzkopf MD (1975) The simplified exchange approximation: a new method for radiative transfer calculations. J Atmos Sci 32:1475-1488

Foley JA, Prentice IC, Ramankutty N, Levis S, Pollard D, Sitch S, Haxeltine A (1996) An integrated biosphere model of land surface processes, terrestrial carbon balance, and vegetation dynamics. Glob Biogeochem Cycles 10:603-628

Foley JA, Levis S, Prentice IC, Pollard D, Thompson SL (1998) Coupling dynamic models of climate and vegetation. Glob Chang Biol 4:561-579

Haxeltine A, Prentice IC (1996) BIOME3: an equilibrium terrestrial biosphere model based on ecophysiological constraints, resource availability, and competition among plant functional types. Glob Biogeochem Cycles 10:693-709. doi:10.1029/96GB02344

Holland MB (2012) Mesoamerican biological corridor. Chapter 5. In: Hilty JA, Chester CC, Cross M (eds) Climate and conservation: landscape and seascape science, planning and action. Island Press/Center for Resource Economics, Washington, pp. 92-103

Huntingford C, Zelazowski P, Galbraith D, et al. (2013) Simulated resilience of tropical rainforests to CO2induced climate change. Nat Geosci 6:268-273

Imbach P, Molina L, Locatelli B, Roupsard O, Mahé G, Neilson R, Corrales L, Scholze M, Ciais P (2012) Modeling potential equilibrium states of vegetation and terrestrial water cycle of Mesoamerica under climate change scenarios. J Hydrometeor 13:665-680. doi:10.1175/JHM-D-11-023.1

Imbach PA, Locatelli B, Molina LG, Ciais P (2013) Leadley PW (2013) climate change and plant dispersal along corridors in fragmented landscapes of Mesoamerica. Ecol Evol 3:2917-2932. doi:10.1002/ece3.672

IPCC (2013) In: Stocker TF, Qin D, Plattner G-K, Tignor M, Allen SK, Boschung J, Nauels A, Xia Y, Bex V, Midgley PM (eds) Climate change 2013: the physical science basis. Contribution of working group I to the fifth assessment report of the intergovernmental panel on climate change. Cambridge University Press, Cambridge 1535 pp. doi:10.1017/CBO9781107415324

Janjić ZI (1984) Nonlinear advection schemes and energy Cascade on semi-staggered grids. Mon Weather Rev 112:1234-1245

Jones C, Lowe J, Liddicoat S, Betts R (2009) Committed terrestrial ecosystem changes due to climate change. Nat Geosci 2:484-487

Jones CD, Hughes JK, Bellouin N, et al. (2011) The HadGEM2-ES implementation of CMIP5 centennial simulations. Geosci Model Dev 4:543-570. doi:10.5194/gmd-4-543-2011

Karmalkar AV, Bradley RS, Diaz HF (2011) Climate change in central America and Mexico: regional climate model validation and climate change projections. Clim Dyn 37:605-629. doi:10.1007/s00382-011-1099-9

Kucharik CJ, Foley JA, Delire C, et al. (2000) Testing the performance of a dynamic global ecosystem model: water balance, carbon balance, and vegetation structure. Glob Biogeochem Cycles 14:795-825

Lacis AA, Hansen J (1974) A parameterization for the absorption of solar radiation in the Earth's atmosphere. J Atmos Sci 31:118-133 
Lyra AA (2015) Estudo de vulnerabilidade do bioma Amazônia aos cenários de mudanças climáticas. Dissertation, National Institute for Space Research

Lyra AA, Chou SC, Sampaio GO (2016) Sensitivity of the Amazon biome to high resolution climate change projections. Acta Amazonica 46:175-188. doi:10.1590/1809-4392201502225

Malhi Y, Grace J (2000) Tropical forests and atmospheric carbon dioxide. Trends Ecol Evol 15:332-337

Malhi Y, Aragao LEOC, Galbraith D, Huntingford C, Fisher R, Zelazowski P, et al. (2009) Exploring the likelihood and mechanism of a climate-change-induced dieback of the Amazon rainforest. Proc Natl Acad Sci U S A 106:20610-20615

Mauri C (2002) Environmental law enforcement and compliance in Central America. Sixth international conference on environmental compliance and enforcement. INECE. April 15-19, 2002, San Jose, Costa Rica. $21 \mathrm{pp}$

Mesinger F (1984) A blocking technique for representation of mountains in atmospheric models. Riv Meteor Aeronautica 44:195-202

Mesinger F, Chou SC, Gomes J, Jovic D, Lazic L, Lyra A, Bustamante J, Bastos P, Morelli S, Ristic I (2012) An upgraded version of the eta model. Meteorog Atmos Phys 116:63-79

Meyers N, Mittermeier RA, Mittermeier CG, da Fonseca GA, Kent J (2000) Biodiversity hotspots for conservation priorities. Nature 403:853-858

Nakicenovic N, Alcamo J, Davis G, et al. (2000) Special report on emissions scenarios: a special report of working group III of the intergovernmental panel on climate change. Cambridge University Press, Cambridge $599 \mathrm{pp}$

Parry ML, Canziani OF, Palutikof JP, van der Linden PJ, Hanson CE (eds) (2007) Contribution of working group II to the fourth assessment report of the intergovernmental panel on climate change. Cambridge University Press, Cambridge

Paulson CA (1970) The mathematical representation of wind speed and temperature profiles in the unstable atmospheric surface layer. J Appl Meteorol 9:857-861

Peng C (2000) From static biogeographical model to dynamic global vegetation model: a global perspective on modelling vegetation dynamics. Ecol Model 135:33-54

Pesquero JF, Chou SC, Nobre CA, Marengo JA (2009) Climate downscaling over South America for 1961-1970 using the eta model. Theor Appl Climatol 99:75-93

Saatchi SS, Harris NL, Brown S, et al. (2011) Benchmark map of forest carbon stocks in tropical regions across three continents. Proc Natl Acad Sci 108:9899-9904

Scholze M, Knorr W, Arnell NW, Prentice IC (2006) A climate change risk analysis for world ecosystems. Proc Natl Acad Sci U S A 103:13116-13120

Stevens B, Bony S (2013) What are climate models missing? Science 340:1053-1054. doi:10.1126/science. 1237554

Zhao Q, Black TL, Baldwin ME (1997) Implementation of the cloud prediction scheme in the eta model at NCEP. Weather Forecast 12:697-712 